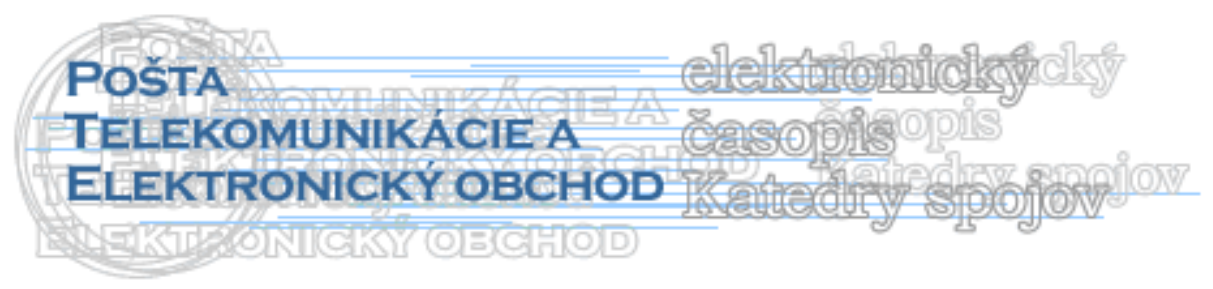

\title{
MERANIE PRIESTOROVEJ DOSTUPNOSTI
}

\author{
Lukáš Achimský*
}

\section{Úvod}

Priestorová dostupnost' ako jeden z faktorov kvality služieb je často rozoberaná téma nakol'ko s ňou súvisia vel'ké náklady. Ide o náklady na jednotlivé pobočky zabezpečujúce priestorovú dostupnost', čiže náklady na prenájom prípadne na výstavbu budov, na kúpu potrebného vybavenia, mzdové náklady na zamestnancov, poistenie atd'. $Z$ tohto dôvodu sa snaží každý poštový operátor optimalizovat' priestorovú dostupnost'.

Optimalizovat' priestorovú dostupnost' znamená určit' počet a umiestnenie pobočiek tak, aby boli náklady súvisiace s počtom pobočiek čo najmenšie a zároveň neklesla zákazníkom vnímaná kvalita služieb pod určitú hodnotu. V prvom rade je potrebné zistit' aká priestorová dostupnost' je pre zákazníka akceptovatel'ná, aby výrazne neznížila jeho pohl'ad na kvalitu služieb. Toto zistenie môže byt' zist'ované dotazníkovým prieskumom, rozhovorom alebo inou metódou, avšak je potrebné realizovat' tento výskum na dostatočne vel'kom počte zákazníkov, aby mal dostatočnú vypovedaciu schopnost'.

Mnohé štúdie zamerané na optimalizáciu priestorovej dostupnosti berú do úvahy vzdušné vzdialenosti od miesta pobočky. Pri výpočtoch vzdialeností predpokladajú s určitou odchýlkou, avšak táto odchýlka je zohl'adnená len percentuálne. To znamená, že ak z výskumu vyplýva, že kvalita služby vnímaná zákazníkom prudko klesá pri vzdialenosti jeho domácnosti od pobočky viac ako 5 kilometrov, do úvahy sa berie vzdušná vzdialenost' od pobočky 4 kilometre. Takúto situáciu znázorňuje obrázok 1 .

Zákazník však na prejdenie k pobočke využíva najmä cestné komunikácie, a tak ním vnímaná vzdialenost' k pobočke môže byt' podstatne väčšia ako vzdušná vzdialenost'. Ako už bolo povedané pri štúdiách priestorovej dostupnosti, ktoré využívajú vzdušnú vzdialenost' je zohl'adnené percento odchýlky, ale môžu nastat' situácie, pri ktorých toto percento bude nepostačujúce. Ide najmä o prípady v územiach kde je nedostatočná infraštruktúra alebo miesta kde sa nachádzajú rôzne prírodné prekážky, cez ktoré nevedú cestné komunikácie (skaly, lesy, rieky atd'.) V týchto prípadoch môže byt' reálna vzdialenost' po cestných komunikáciách značne rozdielna oproti vzdušnej vzdialenosti.

\section{Primárny výskum}

Problematikou priestorovej dostupnosti pôst v sieti národného poštového operátora sa zaoberá inštitucionálny výskum zameraný na meranie skutočných vzdialeností. Tento výskum je aplikovaný na pobočky dodávacích pôšt Slovenskej pošty a.s. a zist'uje rozdiely medzi

\footnotetext{
Ing. Lukáš Achimský, Žilinská univerzita v Žiline, Fakulta PEDAS, Katedra spojov, tel.: +421/0415133145

e-mail: lukas.achimsky@fpedas.uniza.sk
} 
výsledkami štúdií priestorovej dostupnosti vychádzajúcich zo vzdušných vzdialeností a reálnych vzdialeností.

Obrázok 1: Priestorová dostupnost' meraná vzdušnou vzdialenost'ou

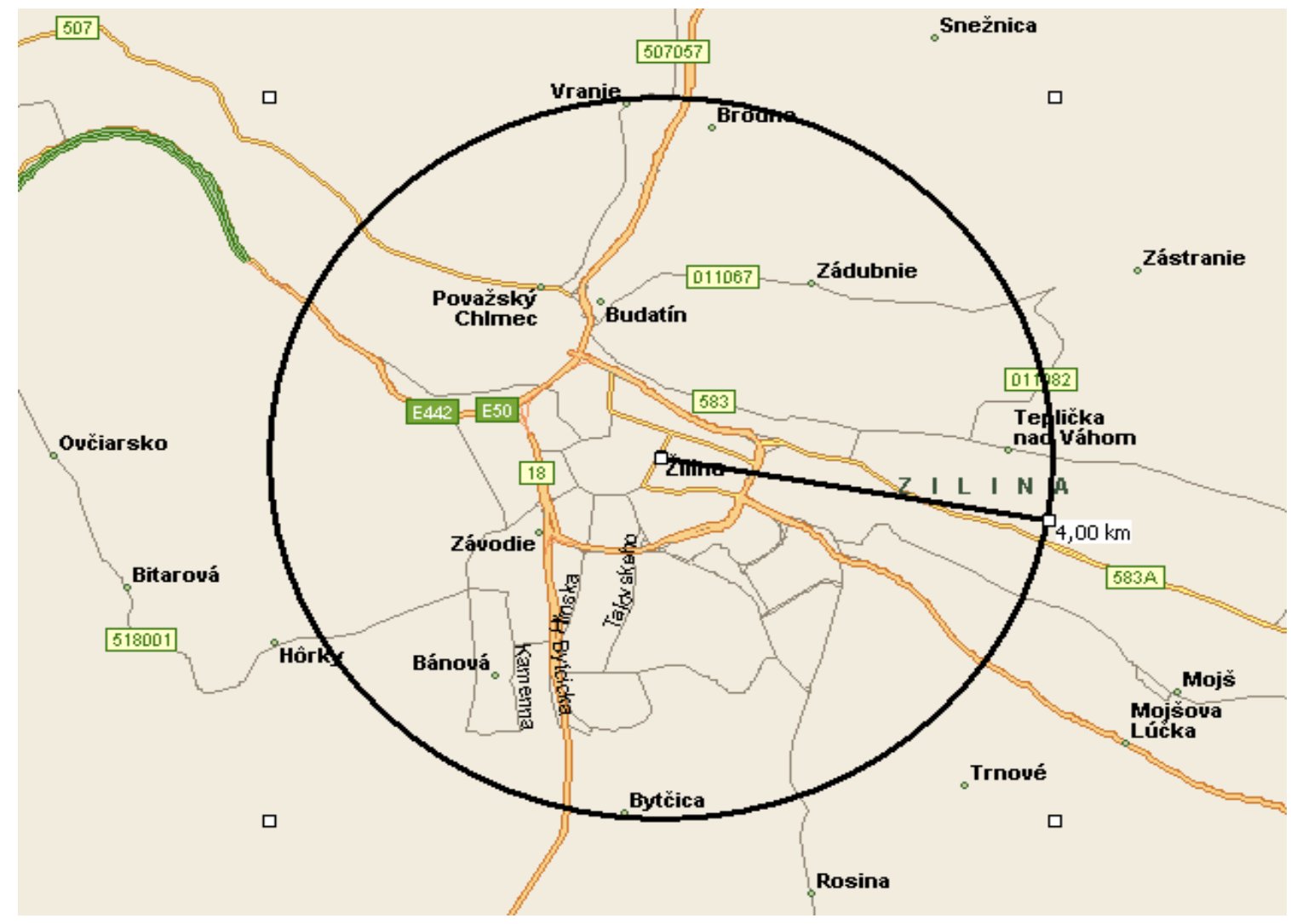

Zdroj: Vlastné spracovanie

Pri výskume platilo, že musia byt' zachované pobočky dodávacích pôšt v mestách a obciach s počtom obyvatel'ov nad 5000 a každá obec na Slovensku musela mat' pobočku pošty v určitej vzdialenosti podl'a normy, ktorú pre Slovenskú poštu a.s. vypracoval Poštový regulačný úrad ako nevyhnutnú vzdialenost' pre zachovanie kvality služieb . Výskum, ktorý bral do úvahy vzdušné vzdialenosti bol realizovaný v programe Autoroute 2010, kde z jednotlivých pobočiek dodávacích pôšt podla vyššie uvedených pravidiel vychádzali kružnice znázorňujúce vzdušné vzdialenosti. Ako už bolo naznačené pri vzdušných vzdialenostiach sa berie do úvahy určitá odchýlka, a tak kružnice mali polomer o $20 \%$ percent menší ako Poštovým regulačným úradom stanovená vzdialenost'.

Vznikla situácia, že mnohé obce a pobočky dodávacích pôšt boli prekryté viacerými kružnicami. Z toho vyplýva, že by bolo eventuálne možné v týchto prípadoch znížit' počet pobočiek dodávacích pôšt. Je však potrebné zachovat' podmienky, že nie je možné zrušit' pobočky v mestách a obciach s počtom obyvatel'ov nad 5000 a každá obec na Slovenku musí mat' pobočku pošty vo vzdialenosti podl'a výsledkov normy (musí sa nachádzat' v kružnici). Situáciu, kde sa nachádzajú pobočky dodávacích pôšt, ktoré je eventuálne možné zrušit' ilustruje obrázok 2.

$\mathrm{Na}$ to, aby navrhované zmeny $\mathrm{v}$ počte a rozložení pobočiek dodávacích pôšt Slovenskej pošty a.s. boli prípustné je potrebná verifikácia reálnych vzdialeností. Na zistenie vzdialeností dvoch konkrétnych bodov je možné použit' rôzne programy, internetová stránky, GPS zariadenia atd'. Pre podmienky výskumu bola použitá internetová stránka www.mapa.zoznam.sk z toho dôvodu, že obsahovala presné umiestnenie väčšiny pobočiek 
Slovenskej pošty a.s. a taktiež zobrazuje obývané časti v jednotlivých obciach, čo urýchl'uje zist'ovanie reálnych vzdialeností (vzdialeností po cestných komunikáciách) od domácností k pobočkám.

\section{Obrázok 2: Situácia znázorňujúca možnost’ zrušenia pobočiek dodávacích pôšt}

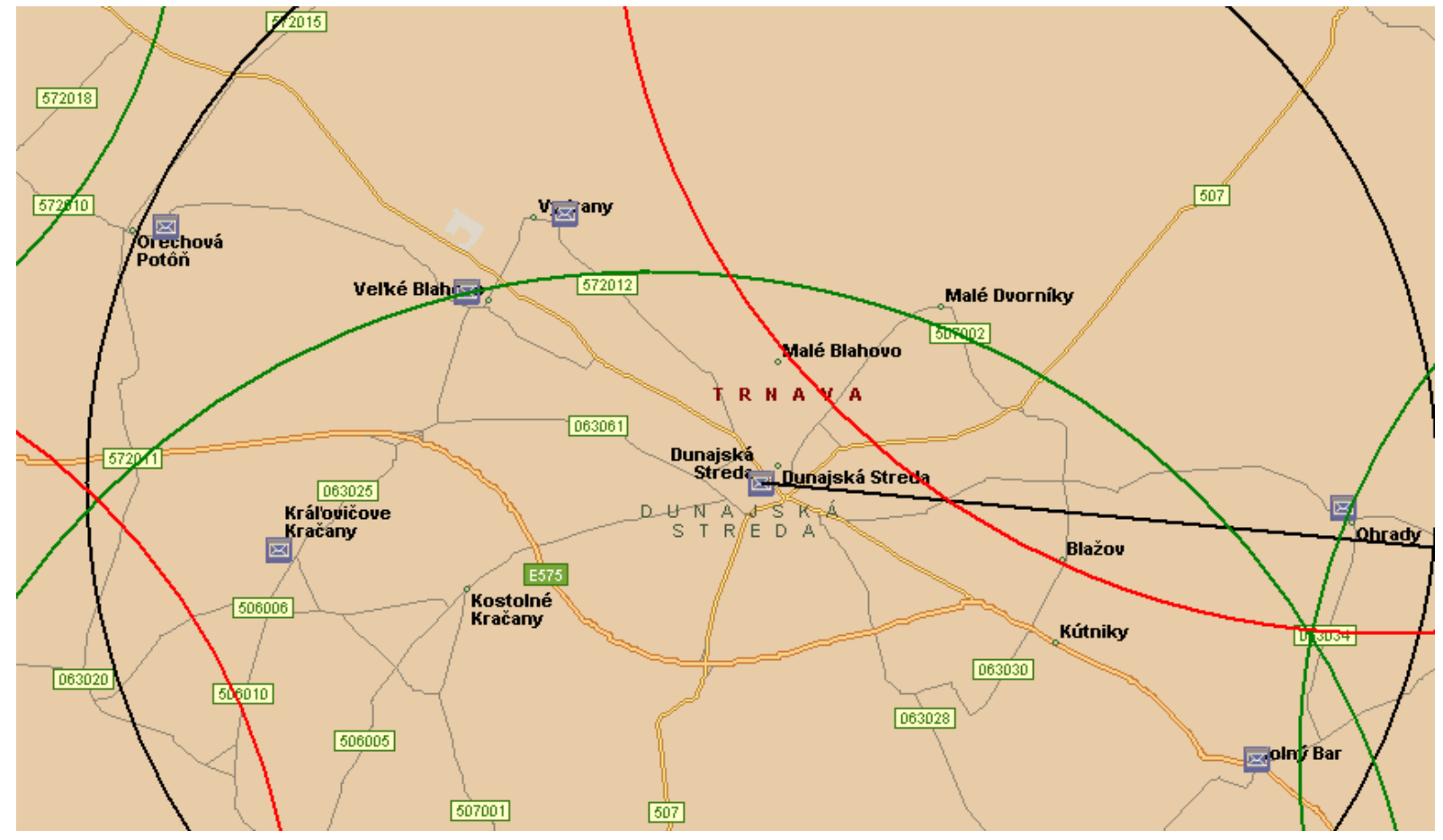

Zdroj: Vlastné spracovanie

V rámci výskumu sa zist’ovali dve reálne vzdialenosti:

- prvá vzdialenost' od domácnosti, ktorá je v danej obci najvzdialenejšia od dodávacej pošty $\mathrm{v}$ súčasnom rozmiestnení dodávacích pôšt,

- druhá vzdialenost' od domácnosti, ktorá je v danej obci najvzdialenejšia od dodávacej pošty po výskumom navrhovaných zmenách v rozmiestnení dodávacích pôšt.

Postup realizácie merania skutočných vzdialeností:

- na danej internetovej stránke sa našla dodávacia pošta pre konkrétnu obec a označila sa ako štart cesty. V prípade, že daná stránka nenašla dodávaciu poštu v danej obci, využila sa stránka www.psc.posta.sk, kde sa nachádzajú presné adresy všetkých pôšt na Slovenku,

- najvzdialenejšia domácnost' obce, pre ktorú sa zist'ovala reálna vzdialenost' sa označí ako ciel' trasy,

- následne vypočítaná reálna vzdialenost' sa zaznamená a takto sa pokračuje pre všetky obce na Slovenku. Názornú ukážku ilustruje obrázok 3.

Po získaní reálnych (skutočných) vzdialeností k dodávacím poštám pre všetky obce na Slovenku nás budú zaujímat' viaceré ukazovatele. V prvom rade pôjde o percento chybných zaradení z výskumu vzdušných vzdialeností k celkového počtu, čiže o počet prípadov, kde reálne vzdialenosti sú väčšie, ako predpisuje norma. 


\section{Obrázok 3: Meranie reálnych vzdialeností}

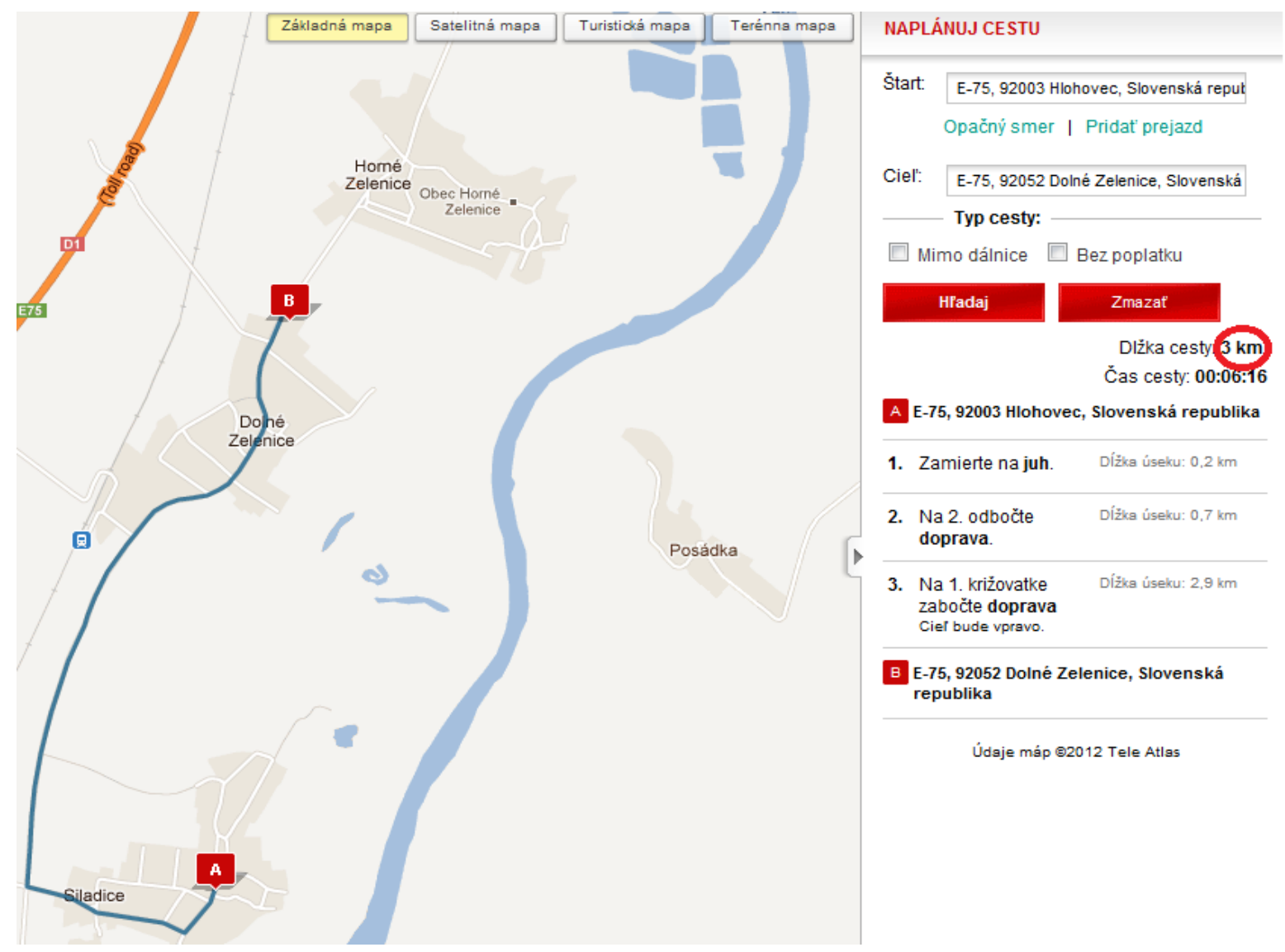

Zdroj: Vlastné spracovanie

Percento chybných zaradení sa vypočíta nasledovne:

$$
x=\frac{n}{N} \times 100
$$

Kde:

$\mathrm{x}$ - percento chybných zaradení

$\mathrm{n}$ - počet chybných zaradení

$\mathrm{N}$ - celkový počet zaradení

Ďalší ukazovatel', ktorý nás bude zaujímat' je priemerná chyba a vypočítame ju nasledovne:

$$
\bar{x}=\frac{\sum_{i=1}^{n}\left(x_{i}-b\right)}{n}
$$

Kde:

$$
\begin{aligned}
& \bar{x} \text { - priemerná chyba } \\
& \mathrm{n} \text { - počet chybných zaradení } \\
& \text { xi - reálna vzdialenost' pre danú obec } \\
& \text { b - normou stanovená vzdialenost' }
\end{aligned}
$$


V poslednom rade nás bude zaujímat' smerodajná odchýlka chyby, ktorú vypočítame nasledovne:

$$
s=\sqrt{\frac{\sum_{i=1}^{n}\left(x_{i}-\bar{x}\right)^{2}}{n}}
$$

Kde:

s - smerodajná odchýlka chyby

$\mathrm{n}$ - počet všetkých chybných zaradení

xi - reálna vzdialenost' pre danú obec

$\bar{x}$ - priemerná chyba $\mathrm{x}$

Ked' vypočítame priemernú chybu a smerodajnú odchýlku môžeme určit' interval chyby. To znamená, že chyba zaradenia je v intervale:

$$
\langle\mathrm{x}-\mathrm{s} ; \mathrm{x}+\mathrm{s}>
$$

Kde:

$\mathrm{x}$ - priemerná chyba

s - smerodajná odchýlka chyby

Ďalej by bolo možné vypočítat' aj iné štatistické ukazovatele, ako je variačný koeficient, variačné rozpätie atd'., ale pre potreby nášho výskumu d'alšie ukazovatele nie sú potrebné.

\section{Záver}

Zist'ovaním reálnych vzdialeností je možné verifikovat' štúdie priestorovej dostupnosti vychádzajúce zo vzdušných vzdialeností a zlepšovat' počet a rozmiestnenie pobočiek pri zachovaní určitej požadovanej priestorovej dostupnosti. Vhodne rozmiestnenie pobočiek môže podniku v značnej miere znížit' náklady pri neznižovaní kvality služieb, čo je jedným z ciel'ov každého podniku.

\section{Literatúra}

[1] Analýza závislostí potrebného počtu prístupových miest od požiadaviek licencie na priestorovú dostupnost', Grand PRU SR, Žilina, 2010, 62 str.

[2] Adresy pôšt dostupné na: < www.psc.posta.sk >

[3] Mapa Slovenska dostupné na: < http://mapa.zoznam.sk/ >

\section{Grantová podpora}

Článok je súčast'ou riešenia úlohy inštitucionálneho výskumu - Analýza citlivosti počtu kontaktných miest v pomere k nákladom plynúcim z poskytovania UPS. 